\title{
Bentuk Tanda dalam Naskah Lontaraq Pananrang Masyarakat Desa Lise: Kajian Semiotika Pierce
}

\author{
Abdul Hafid \\ Dosen Bahasa Indonesia \\ Fakultas Ilmu Sosial dan Ilmu Politik Universitas Sulawesi Barat Majene, 91214 \\ abdulhafidtahir@unsulbar.ac.id
}

\begin{abstract}
Abstrak
Penelitian ini bertujuan mendeskripsikan bentuk tanda lontaraq pananrang orang Lise. Penelitian ini merupakan jenis penelitian kualitatif dengan metode deskriptif. Sumber data diperoleh dari naskah Lontaraq. Hasil penelitian ini menunjukkan bahwa tanda dalam naskah lontaraq pananrang atau allaonrumang berbentuk kata dan frasa. Kata dan frasa merupakan referen dari bentuk dan posisi bintang yang muncul setiap tanggal pada bulan tertentu. Tanda yang mereka ambil adalah manuq (ayam), tékkosorong (bajak tradisional), woromporong, watampatang, walu, tanra, lambaru, éppang, dan wara-wara. Hal yang mendasar ditemukan dalam penelitian ini adalah dalam hal penentuan tanda. Masyarakat Bugis dalam menentukan sebuah tanda selalu berpatokan pada budaya, mengambil benda-benda yang ada di sekitarnya yang dikenal masyarakat, sedangkan Pierce menentukan sebuah tanda berdasarkan logika. Wujud tanda yang diambil dari budaya berupa benda, hewan, dan tumbuh-tumbuhan yang mudah dikenal, ditemukan dan digunakan oleh masyarakat Desa Lise.
\end{abstract}

Kata kunci: Bentuk, Lontaraq, tanda.

\section{Pendahuluan}

Salah satu kearifan lokal yang ada di nusantara adalah bahasa dan budaya daerah. Bahasa daerah merupakan salah satu bahasa yang dikuasai oleh hampir seluruh anggota masyarakat pemiliknya yang tinggal di daerah itu. Wajar jika adat, kebiasaan, tradisi, tata nilai dan kebudayaan masyarakat lingkungannya juga terekam di dalam bahasa daerah tersebut.

Dalam bidang mata pencaharian suku Bugis, sebagian menjadi petani, nelayan, beternak dan pedagang. Orang Bugis yang mata pencahariannya sebagai pelaut mencari kehidupan dan mempertahankan hidup dari laut. Mereka membaca bintang di langit, melihat tanda-tanda alam seperti gelombang, arus laut, serta semilir angin, tidak selamanya bergantung pada alat modern. Kemampuan membaca tanda-tanda alam, seorang nelayan (pelaut) berani mengarungi laut dengan menggunakan perahu pinisinya untuk mencari ikan ataukah berdagang.

Mata pencaharian masyarakat desa Lise di samping bertani juga beternak. Petani yang mempunyai lahan persawahan dan perkebunan yang belum memakai irigasi, mereka masih mengandalkan curah hujan. Irigasi yang ada, belum bisa menjangkau semua lahan persawahan, karena jarak saluran irigasi dengan lahan persawahan, di samping letak persawahan masih ada yang lebih tinggi dari.

Petani dalam mengolah lahan pertaniannya sudah menggunakan peralatan pertanian modern, tetapi faktor yang paling utama dibutuhkan dalam bercocok tanam adalah persediaan air yang cukup selama musim tanam, bukan peralatan yang modern. 
Pengetahuan yang mereka peroleh, baik ilmu perbintangan ataupun pengetahuan tentang fauna diperoleh dari orang tua mereka dahulu, yang diwariskan ke anak cucunya dalam bentuk sebuah naskah kuno yang dikenal dengan lontaraq pananrang. Setiap daerah mempunyai pananrang sendiri diwarisinya secara turun temurun dan menjadi pedoman dalam mengelola dan menggarap lahan pertaniannya. seperti halnya pananrang yang ada di Desa Lise.

\section{Metode}

Penelitian ini dilakukan di Desa Lise Kecamatan Panca Lautang Kabupaten Sidrap. Jenis penelitian yang digunakan adalah penelitian kualitatif dan metode deskriptif dengan pendekatan Semiotika Pierce.

Penelitian ini mengambil sumber data dari naskah Lontaraq yang disusun oleh Sjamsuddin Muhalli di Lise, 2 Nopember 1965 bertepatan dengan 8 Rajab 1385 Hijriah. Naskah ini diambil sebagai objek penelitian karena naskah ini masih berada di tengah-tengah masyarakat Desa Lise. Isi naskah terdiri dari, kata pendahuluan, jumlah bab sebanyak 22, dan jumlah halaman sebanyak 41 halaman. Naskah ini berupa buku dengan lembaran kertas. Ada 3 jenis huruf yang digunakan yakni: huruf latin, huruf Arab, dan huruf lontaraq Bugis.

Teknik pengumpulan data adalah data diambil secara langsung dari naskah lontaraq dengan memilih bagian yang berhubungan dengan pertanian. Dalam penelitian ini, yang objek penelitian adalah Prihal Pananrang Pertanian (allaonrumae) terdapat pada halaman 11a - 26a dalam naskah lontaraq.

\section{Hasil}

Hasil penelitian tentang 'tanda' dalam naskah lontaraq pananrang atau allaonrumang berbentuk kata dan frasa. Kata dan frasa merupakan referen dari bentuk dan posisi bintang yang muncul setiap tanggal pada bulan tertentu. Tanda yang mereka ambil adalah manuq (ayam), tékkosorong (bajak tradisional), woromporong, watampatang, walu, tanra, lambaru, éppang, dan wara-wara.

Masyarakat Bugis dalam menentukan sebuah tanda selalu berpatokan pada budaya, mengambil bendabenda yang ada di sekitarnya yang sudah dikenal masyarakat, sedangkan Pierce selalu menentukan sebuah tanda berdasarkan logika. Wujud tanda yang diambil dari budaya berupa benda, hewan, dan tumbuh-tumbuhan yang mudah dikenal, ditemukan dan digunakan oleh masyarakat Desa Lise. Pemberian tanda yang mereka tempuh adalah dengan melihat keterkaitan antara pengambilan penanda dengan penjelasan yang terdapat dalam naskah lontaraq pananrang. Dalam arti lain, tanda yang menjadi tanda (sign) merupakan suatu fenomena yang terkait dengan faktor eksternal atau kenyataan aktual (sinsign) kemudian meningkat ke kesepakatan (legisign), dalam teori trikotomi Pierce.

\section{Pembahasan}

Tanda dalam naskah Lontaraq Pananrang memiliki beberapa bentuk. Pembahasan berikut berpusat pada bentuk fisik sebuah tanda melalui latar (ground). Bentuk tanda dibagi menjadi tiga jenis berdasarkan dasarnya (ground) yaitu: qualisign, sinsign dan legisign.

Pada bagian Lontaraq Pananrang tanda yang digunakan untuk menandai hari setiap bulan adalah berdasarkan bintang yang muncul pada malam hari. Petani atau para pelaut tradisional menggunakan bintangbintang sebagai alat untuk mengetahui mata angin, petunjuk arah, dan curah hujan yang bakal turun. Sebahagian Masyarakat Desa Lise hanya mengenalnya saja, tapi tidak mengenal bintang apa namaya menurut ilmu Astronomi. Ada nama-nama khusus yang diberikan untuk gugus bintang tertentu, yakni sebagai berikut: 


\section{1. Éppang}

Informasi berbagai sumber mengartikan éppang diartikan lumpuh. Penandaan eppangé dalam naskah Lontaraq Pananrang merujuk kepada posisi bintang selatan, posisi bintang tidak tegak lurus antara bintang Acrus dengan Gacrus.

Pada tataran Representamen (R), bentuk fisik sebuah tanda terlihat lima buah bintang terang yang mempunyai sifat keterkaitan dengan sebuah bangunan yang tidak cukup tiangnya. Bangunan yang demikian akan pincang dalam bahasa Bugis képpang. Dalam trikotomi tanda Pierce, bangunan 'képpang' berpotensi menjadi penanda dari bintang lima, yang dinamakan qualisign. Pemberian nama tanda memiliki keterkaitan (sinsign) terjadi karena adanya norma yang terkandung dalam suatu tanda, bintang yang berjumlah 5 dikaitkan dengan bangunan yang pincang karena jumlah tiangnya yang tidak seimbang, kemudian meningkat ke kesepakatan menjadi éppang (legisign).

Pada tataran kedua Trikotomi Pierce yakni hubungan dengan objek, éppang atau képpang menjadi ikon lima bintang yang muncul di langit selatan. Éppang berarti mengindeks ke lima bintang di langit Selatan, sekaligus menjadi simbol apabila éppang muncul pada Januari $(1,8$, dan 9) pertanda baik menanam terutama tanaman kapas dan akan ada hujan. April (23, 24 dan 28) pertanda baik, akan ada hujan. Mei (1) pertanda tidak baik menanam dan akan ada hujan. September $(8,9)$ pertanda tidak baik.

2. Lambaru

Masyarakat Desa Lise mengenal lambaru. Lambaru adalah nama layang-layang yang berukuran besar yang dikendalikan oleh seutas tali. Diterbangkan dengan ketinggian rata-rata 100 meter. Penandaan lambaru dalam naskah lontaraq pananrang merujuk kepada posisi bintang pari. Interpretasi peneliti, mengatakan bahwa bintang pari di beri penanda lambaru karena posisi bintang menyerupai orang yang bermain lambaru (layang-layang). Pemberian nama rasi bintang pari ini, setiap daerah mempunyai penamaan lain seperti rasi layang-layang, rasi gubuk penceng, rasi salib selatan, rasi ikan pari dan masih banyak nama lainnya bergantung kesepakatan orang diwilayah itu menamakannya.

Pada tataran Representamen (R), dalam hal ini bentuk fisik sebuah tanda terlihat enam buah bintang terang yang mempunyai sifat keterkaitan dengan menggambarkan orang yang sedang bermain layang-layang. Layang-layang, dalam masyarakat Desa Lise menyebutnya tedaq-tedaq yang bentuknya segi empat. Tedaq-tedaq hanya dimainkan oleh anak-anak belasan tahun, karena memang jangkauan terbangnya terbatas dan tidak terlalu membutuhkan tenaga untuk menahannya, sedangkan lambaru berukuran besar dan bisa terbang tinggi dan membutuhkan tenaga untuk menahan waktu dimainkan. Dalam trikotomi tanda Pierce, 'lambaru' berpotensi menjadi penanda dari enam buah bintang terang, yang dinamakan qualisign.

Interpretasi peneliti tentang penamaan bintang tersebut, karena lambaru terbangnya tinggi dan khusus orang dewasa yang memainkannya, hal lain posisi bintang tersebut mirip juga dengan bentuk ikan Pari, namun dikarenakan Desa Lise posisinya jauh dari pantai sehingga kemungkinan besar orang tua dulu belum pernah melihat bentuk ikan Pari. Pemberian nama tanda memiliki keterkaitan (sinsign) terjadi karena adanya norma yang terkandung dalam suatu tanda, bintang yang berjumlah 6 dikaitkan dengan mainan layang-layang orang dewasa, kemudian meningkat ke kesepakatan menjadi lambaru (legisign).

Pada tataran kedua Trikotomi Pierce yakni hubungan dengan objek, lambaru menjadi ikon enam bintang yang muncul di langit selatan. Jadi dalam naskah lontaraq pananrang tertulis lambaru berarti mengindeks ke enam bintang di langit Selatan, sekaligus menjadi simbol Penunjuk arah Selatan, lambaru muncul pada Maret (7). April (30). Juli (26 dan 31). November (17, 18) pertanda ada hujan tiga malam, pertanda musim timur, bertiup angin musim Barat tiga hari, biasanya ada angin kencang.

3. Manuq 
Masyarakat Desa Lise mengenal manuq adalah ayam. Penandaan manuq dalam naskah lontaraq pananrang merujuk kepada posisi tiga bintang terang yang kalau ditarik garis lurus membentuk segitiga besar di langit yang diberi nama Summer Triangle. Dalam ilmu Astronomi ketiga bintang itu adalah Vega (dari rasi Lyra), Altair (dari rasi Aquila), dan Deneb (dari rasi Cygnus), selalu muncul pada posisi sebelah utara. Interpretasi peneliti, mengatakan bahwa posisi tiga bintang terang di beri penanda manuq karena posisi bintang menyerupai ayam yang sedang terbang dilihat pada posisi kejauhan.

Pada tataran Representamen (R), dalam hal ini bentuk fisik sebuah tanda terlihat tiga buah bintang terang yang mempunyai sifat keterkaitan dengan ayam terbang dari kejauhan. Dalam trikotomi tanda Pierce, ' manuq' berpotensi menjadi penanda dari tiga buah bintang terang, yang dinamakan qualisign. Pemberian nama tanda memiliki keterkaitan (sinsign) terjadi karena adanya norma yang terkandung dalam suatu tanda, bintang yang berjumlah tiga dikaitkan dengan ayam besar yang terbang dikejauhan, kemudian meningkat ke kesepakatan menjadi manuq (legisign).

Pada tataran kedua Trikotomi Pierce yakni hubungan dengan objek, manuq menjadi ikon enam bintang yang muncul di langit selatan. Dalam ilmu Astronomi, apabila ketiga bintang itu muncul pertanda musim panas akan segera tiba, bagi orang-orang yang tinggal di belahan bumi utara yang mengenal 4 musim. Di Indonesia tidak ada istilah musim panas, tetapi tetap dapat melihat ketiga bintang tersebut. Jadi dalam naskah lontaraq pananrang tertulis manuq berarti mengindeks ketiga bintang di langit sebelah Utara, sekaligus menjadi simbol Penunjuk arah Utara dan beberapa pemaknaan tertentu. Manuq muncul pada Januari (1) pertanda baik menanam kapas, (16) pertanda baik, dan (26) pertanda kalau ada diserang penyakit akan mati. Februari (4) pertanda musim Barat satu bulan, dan (5) diberi nama Mawosongé. Maret $(19,22)$ pertanda keramat tiga hari, yang diberi nama La Puruasu, (26, 30). April (2) dinamakan La Temmabbombang, (3) pertanda tigabelas malam hujan, baik menanam padi, (5) pertanda mubazir dan (7) pertanda ada hujan insya Allah. Juni $(20,25)$. Juli $(5,10)$ pertanda pamali pergi merantau, $(25)$ dinamakan La Mattoanging, dan (29) pertanda waktunya pohon kemiri berbunga. September (28, 29). Oktober (2) pertanda menanam Gandum di tanah Arab, (3) pertanda baik dinamakan La Temmaukkeng, $(4,5,9,12)$ pertanda hujan deras waktu sore, (13) dinamakan La Massajang Rennu, (14) dinamakan Talloseq, kalau dingin pertanda musim Barat akan panjang, (15, 17, 18 dan 23) dinamakan La Sakkatemme, dan (29) pertanda baik. Desember (12) pertanda anak yang lahir akan murah rezekinya, dan (27) dinamakan $\mathrm{La}$ Mattoanging.

\section{Woromporong}

Masyarakat Desa Lise mengenal woromporong adalah benda berkelompok-kelompok. Penandaan woromporong dengan melihat sebuah gugusan bintang yang bernama Pleiades dalam ilmu Astronomi atau yang dijuluki sebagai Bintang Tujuh, karena kalau dilihat tanpa menggunakan teleskop hanya tujuh bintang yang jelas bersinar. Gugus bintang ini dapat diamati di seluruh Indonesia bila langit cerah.

Dalam naskah lontaraq pananrang penandaan woromporong merujuk kepada posisi Bintang Tujuh. Ketujuh Bintang yang dimaksud, dalam ilmu Astronomi adalah: Alcyone, Celaeno, Electra, Maia, Merope, Taygeta, dan Sterope. Interpretasi peneliti, mengatakan bahwa posisi Bintang Tujuh tersebut masing-masing memiliki kelompok tersendiri, dalam bahasa lontaraq pananrang dikenal woromporong.

Pada tataran Representamen (R), dalam hal ini bentuk fisik sebuah tanda terlihat tujuh buah bintang terang yang mempunyai sifat keterkaitan dengan rumput yang tumbuh membentuk rumpun atau kelompok. Rumput tersebut mudah tumbuh di lahan persawahan dan perkebunan. Dalam trikotomi tanda Pierce, 'woromporong' berpotensi menjadi penanda dari tujuh buah bintang terang, yang dinamakan qualisign. Pemberian nama tanda memiliki keterkaitan (sinsign) terjadi karena adanya norma yang terkandung dalam suatu tanda, bintang yang berjumlah tujuh dikaitkan dengan tumbuhan yang sering tumbuh di lahan persawahan secara berkelompok, kemudian meningkat ke kesepakatan menjadi woromporong (legisign). 
Dalam trikotomi tanda Pierce di kenal dengan istilah sinsign, artinya tanda dengan pemberian nama memiliki keterkaitan, kemudian meningkat ke kesepakatan menjadi woromporong yang merujuk ke tujuh bintang terang di langit Utara, dalam teori Pierce disebut legisign.

Pada tataran kedua Trikotomi Pierce yakni hubungan dengan objek, woromporong menjadi ikon tujuh bintang yang muncul di langit Utara. Dalam ilmu Astronomi, ketujuh bintang itu muncul sepanjang tahun sebagai penunjuk arah Utara. Keistimewaan yang dimiliki bintang ini adalah satu-satunya bintang yang tidak pernah berpindah tempat sejak pertama kali ditemukan. Jadi dalam naskah lontaraq pananrang tertulis woromporong berarti mengindeks ketujuh bintang di langit sebelah Utara, sekaligus menjadi simbol penunjuk arah Utara dan beberapa pemaknaan tertentu. Woromporong muncul pada bulan Januari (22) pertanda hujan atas izin Allah swt., $(25,26)$ pertanda kalau ada diserang penyakit akan mati, $(27)$ pertanda hujan tiga malam, dan (28) pertanda hujan insya Allah. April $(24,27)$ pertanda kepiting berisi dan baik untuk menanam. Mei $(17,18)$ pertanda hujan, $(23,30)$ pertanda baik menanam dan melakukan pesta perkawinan. Agustus (7) pertanda baik menanam kacang hijau, pohon Randu berbunga dan hujan insya Allah, (8) pertanda pertengahan musim timur, (10) pertanda pohon kapuk berbunga, $(13,14,15)$ dinamakan talloseq atau hari wafatnya Nabi Isa as., (16) pertanda baik menanam kacang hijau, pohon mangga berbunga dan hujan, $(19,20)$. November (22) kalau ada angin dan hujan pertanda musim Barat akan singkat di tanah kelahiran, dan (29) pertanda tidak baik membuat perkakas. Desember (1) pertanda musim Barat Lima, (2) pertanda baik menanam padi, permulaan musim Barat duaratus malam, dingin, baik menanam tanaman berbuah, tetapi tidak baik membangun rumah dan (18) pertanda ada angin bertiup selama tujuh malam.

\section{Watampatang}

Masyarakat Desa Lise mengenal watampatang adalah benda berbentuk batang. Penandaan watampatang dengan melihat sebuah gugusan bintang.

Dalam naskah lontaraq pananrang penandaan watampatang merujuk kepada posisi yang berbentuk seperti batang. Pada tataran Representamen (R), dalam hal ini bentuk fisik sebuah tanda terlihat gugusan bintang yang mempunyai sifat keterkaitan dengan sesuatu yang berbentuk batang. Masyarakat Desa Lise mengasumsikan dengan watampatang. Watampatang yang dimaksudkan oleh masyarakat Desa Lise adalah jamur yang tumbuh dari kotoran ternak yang sudah kering. Interpretasi peneliti, pemberian nama watampatang pada gugusan bintang ini, karena sepintas kelihatan hanya berbentuk batang tanpa menggunakan teleskop. Dalam trikotomi tanda Pierce, 'watampatang' berpotensi menjadi penanda dari gugusan bintang yang terlihat berbentuk batang, dinamakan qualisign. Pemberian nama tanda memiliki keterkaitan (sinsign) terjadi karena adanya norma yang terkandung dalam suatu tanda, gugusan bintang dengan watampatang, jamur yang tumbuhan pada kotoran ternak yang sudah kering, kemudian meningkat ke kesepakatan menjadi watampatang (legisign).

Pada tataran kedua Trikotomi Pierce yakni hubungan dengan objek, watampatang menjadi ikon gugusan bintang yang muncul di langit. Dalam ilmu Astronomi, gugusan bintang tersebut mempunyai inti (pusat) yang berbentuk roda atau batang. Watampatang berarti mengindeks ke gugusan bintang dengan pemaknaan tertentu. Watampatang muncul pada Januari (1) pertanda baik. Maret (2) dinamakan $L a$ Madiwu La Makkasolang Solang pertanda tidak baik. April (4, 11). Juni (5) pertanda tidak baik menanam padi, dan (10) kalau ada hujan pertanda Musim Timur lemah. Agustus (28) pertanda akan hujan atas izin Allah swt. September (3) pertanda akan ada hujan deras dan 25 pertanda baik, dinamakan hari Arung Mangkau. Desember (22).

6. Wara-wara

Masyarakat Desa Lise mengenal wara-wara diartikan bara-bara, apabila kelihatan warna merah di kaki langit/cakrawala seperti obor, siang hari banyak hembusan angin tidak terarah, hawa pengap, dan kering. 
Pada tataran Representamen (R), dalam hal ini bentuk fisik sebuah tanda terlihat panorama langit sebelah Barat di sore hari berwarna merah. Masyarakat Desa Lise mengasumsikan dengan wara-wara. Wara-wara yang dimaksudkan oleh masyarakat Desa Lise adalah sesuatu yang menyerupai bara api. Dalam trikotomi tanda Pierce, 'wara-wara' berpotensi menjadi penanda dari panorama langit di sore hari yang berwarna merah, dinamakan qualisign. Pemberian nama tanda memiliki keterkaitan (sinsign) terjadi karena adanya norma yang terkandung dalam suatu tanda, panorama sore hari dengan wara-wara, langit berwarna merah, kemudian meningkat ke kesepakatan menjadi wara-wara (legisign).

Pada tataran kedua Trikotomi Pierce yakni hubungan dengan objek, wara-wara menjadi ikon panorama sore hari muncul di langit. Wara-wara berarti mengindeks ke panorama sore hari dengan pemaknaan tertentu. wara-wara muncul pada Februari (6) pertanda kurang baik, (8) kalau ada hujan pertanda tanaman akan subur insya Allah serta dingin kering, (9) pertanda kurang baik, (10) pertanda keramat dinamakan La Makkanre Api, $(11,12)$ pertanda baik membuat peralatan Nelayan. Mei (11) pertanda hujan insya Allah. Agustus $(22,25)$ kalau ada anak lahir pertanda akan berumur pendek, (27) pertanda hujan keras, (28) pertanda keramat dinamakan La Makkanre Api, (29, 30) dinamakan talloseq. September (7) dinamakan La Kamallise. Desember (16) pertanda hujan, Musim Barat Tujuh dan (17) pertanda akan hujan lima malam.

\section{Walu}

Masyarakat Desa Lise mengenal walu diartikan istri tanra. Tanra yang dimaksud adalah salah satu bentuk tanda yang digunakan sebagai penanda dalam naskah lontaraq pananrang. Walu yang dimaksud dalam naskah lontaraq pananrang adalah salah satu bintang yang terdapat di dekat bintang Salib Selatan.

Pada tataran Representamen (R), dalam hal ini bentuk fisik sebuah tanda terlihat delapan bintang, tiga sejajar dan dikelilingi 5 bintang yang terang. Masyarakat Desa Lise menyebutnya dengan istri tanra karena bintang tersebut berada disekitar tanra. Tanra yang di maksudkan yaitu tiga bintang berjajar. Dalam trikotomi tanda Pierce, 'walu' berpotensi menjadi penanda dari 5 bintang yang terang yang mengelilingi tiga bintang terang 'tanra', dinamakan qualisign. Pemberian nama tanda memiliki keterkaitan (sinsign) terjadi karena adanya norma yang terkandung dalam suatu tanda, bintang yang berada pada posisi dekat tanra (bintang berjajar tiga) dengan walu, sebagai istri tanra kemudian meningkat ke kesepakatan menjadi walu (legisign).

Pada tataran kedua Trikotomi Pierce yakni hubungan dengan objek, walu menjadi ikon 8 bintang yang muncul di langit. Walu muncul pada Januari $(19,21)$ pertanda baik menanam padi dan hujan sembilan malam, (24) pertanda baik menanam kapas, hujan tiga hari, (27, 29 dan 31) pertanda tiga malam hujan. Februari $(1,2)$ pertanda baik menanam ubi, kapas dan tebu, $(3,12)$ pertanda baik membuat alat nelayan, (13) pertanda baik menanam Aladi dan peralatan nelayan, dan (24) baik secara inti. April (1, 21, dan 22) pertanda baik membuat peralatan nelayan. Mei $(5,7,8,14$, dan 21) pertanda baik menanam wijen, pasang dan padi. Juni $(14,22)$ kalau hujan pertanda banyak orang sakit di dalam kampung, dan (26) pertanda berakhir hujan deras. Juli (24). Agustus (3) pertanda tidak baik menanam dan apa saja dikerjakan. Oktober (28, dan 31) pertanda baik menanam tanaman yang berbuah. November (1) pertanda baik untuk menanam, $(5,7)$ pertanda baik menanam kelapa, kalau ada banjir pertanda musim Timur dingin, (13) pertanda waktunya menanam betteng dan kacang hijau serta hujan deras atas kehendak Allah swt., dan (26) pertanda tidak baik menanam padi, membangun rumah, perkawinan, tidak baik semua. Desember $(3,8)$ pertanda tidak baik menanam padi, tidak akan dimakan yang punya padi, (13) pertanda akan ada hujan, (18) pertanda ada angin bertiup, (23) ada angin berhembus sebentar, pertanda musim Barat akan baik, dan (28) pertanda berakhirnya menanam kacang hijau.

8. Tékkosorong

Masyarakat Desa Lise mengenal tékkosorong diartikan Bajak tradisional yang ditarik oleh binatang seperti kerbau, sapi, atau kuda. Bajak digunakan sebagai penanda dalam naskah lontaraq pananrang dengan melihat bintang di langit, kalau ditarik garis menghubungkan antara bintang satu dengan bintang lainnya, 
kelihatan mirip bajak yang mereka gunakan dalam mengolah tanah persawahan. Bintang yang dimaksud adalah rasi Bintang Waluku.

Pada tataran Representamen (R), dalam hal ini bentuk fisik sebuah tanda terlihat lima bintang. Masyarakat desa Lise menyebutnya dengan tekkosorong (artinya bajak dorong). Dalam trikotomi tanda Pierce, 'tékkosorong' berpotensi menjadi penanda dari 5 bintang yang terang, istilah ilmu Astronomi dinamakan rasi Bintang Waluku, dinamakan qualisign. Pemberian nama tanda memiliki keterkaitan (sinsign) terjadi karena adanya norma yang terkandung dalam suatu tanda, bintang Waluku dengan tekkosorong, kemudian meningkat ke kesepakatan menjadi tekkosorong (legisign).

Pada tataran kedua Trikotomi Pierce yakni hubungan dengan objek, tékkosorong menjadi ikon bintang Waluku. Jadi dalam naskah lontaraq pananrang tertulis tékkosorong berarti mengindeks ke bintang Waluku dengan pemaknaan tertentu. Tekkosorong muncul pada Januari (11) Hujan empat malam nawellampajungé pertanda baik ditanami padi, Sepuluh malam hujan serta baik anak yang lahir. Mei (1) pertanda akan hujan serta tidak baik menanam. Juli (31) pertanda tidak baik.

9. Tanra

Masyarakat Desa Lise mengenal tanra. Tanra yang dimaksud adalah tampak bintang sejajar tiga dilangit malam. Dalam ilmu Astronomi yang dihimpun dari berbagai sumber bintang yang sejajar tiga tersebut adalah rasi Orion memiliki ciri yang sangat mencolok yaitu 3 bintang sejajar ditengahnya dan 2 bintang di kanan kirinya. Ketiga bintang sejajar itu bernama: mintaka, alnilam dan alnitak memiliki jarak yang sangat berjauhan. Mintaka berjarak 900 tahun cahaya, Alnilam 1.359 tahun cahaya dan Alnitak 800 tahun cahaya. Disebelah kanan bintang 3 tersebut adalah Nebula atau awan antar bintang. Nebula adalah tempat dimana bintang-bintang dilahirkan atau dengan kata lain Nebula adalah rahimnya para bintang. Dalam naskah lontaraq pananrang digunakan sebagai penanda.

Pada tataran Representamen (R), dalam hal ini bentuk fisik sebuah tanda terlihat tiga bintang. Masyarakat Desa Lise menyebutnya dengan tanra. Dalam trikotomi tanda Pierce, 'tanra' berpotensi menjadi penanda dari 3 bintang yang terang, istilah ilmu Astronomi dinamakan rasi Orion, dinamakan qualisign. Pemberian nama tanda memiliki keterkaitan (sinsign) terjadi karena adanya norma yang terkandung dalam suatu tanda, bintang berjajar tiga (Nebula Orion) dengan tanra, kemudian meningkat ke kesepakatan menjadi tanra (legisign).

Pada tataran kedua Trikotomi Pierce yakni hubungan dengan objek, tanra menjadi ikon bintang berjajar tiga. Tanra muncul pada bulan Januari $(6,14)$ pertanda lima hari hujan musim barat sembilan. Februari $(15,19,20,22,23,25,26$, dan 28) pertanda baik menanam padi. Maret (1) pertanda hujan menggenangi, $(2,3)$ pertanda baik, (4) pertanda baik menanam wijen, $(6,9)$ pertanda hari baik, (10) pertanda baik menanam wijen, $(11,14)$ pertanda Pohon Awerangé berbunga, hujan, serta baik menanam padi, dan $(18)$ pertanda baik menanam padi. Mei $(22)$ pertanda baik untuk perkawinan, $(26,31)$ pertanda baik, hujan atas izin Allah swt. Juni $(4,8)$ pertanda kepeting berisi, (12) pertanda tidak baik menanam padi, $(24,28)$ pertanda hari Arung Mangkaui namanya, hujan menggenangi atas izin Allah. Juli (2) pertanda hari baik, apa saja dikerjakan akan baik, kalau bertepatan hari Jumat bulan purnama, pertanda baik. September (10, $11,12)$ pertanda kebakaran, $(14)$ pertanda hujan insya Allah, (15) pertanda baik, $(17,18)$ pertanda, keramat La Mapatuddu La Makkasolang Solang pasti merusak, (19) dinamakan talloseq, (20, 21) pertanda hari keramat, $(22,28)$ pertanda baik. Oktober (20). November (19) pertanda Waktu tanamnya kacang hijau di lahan dan di gunung, (23) pertanda anak yang lahir akan rakus, dan (26) pertanda tiga malam hujan. Desember (1, 4, dan 3) pertanda baik menanam kelapa, baik juga menanam ubi Jawa.

\section{Kesimpulan dan Saran}

Tanda dalam naskah lontaraq pananrang atau allaonrumang berbentuk kata dan frasa. Kata dan frasa merupakan referen dari bentuk dan posisi bintang yang muncul setiap tanggal pada bulan tertentu. Kata dan 
frasa ini dijadikan sebagai "tanda" merujuk ke rasi bintang yang muncul pada malam hari kemudian diberi petanda yang mereka kenal dalam kehidupan sehari-hari untuk memudahkan mengenal bintang tersebut. Tanda yang mereka ambil adalah manuq (ayam), tékkosorong (bajak tradisional), woromporong, watampatang, walu, tanra, lambaru, éppang, dan wara-wara. Pemberian tanda yang mereka tempuh adalah dengan melihat keterkaitan antara pengambilan penanda dengan penjelasan yang terdapat dalam naskah lontaraq pananrang. Dalam arti lain, tanda yang menjadi tanda merupakan suatu fenomena yang terkait dengan faktor eksternal atau kenyataan aktual, disebut dengan sinsign kemudian meningkat ke kesepakatan, dalam teori trikotomi Pierce disebut legisign.

Masyarakat Bugis dalam menentukan sebuah tanda selalu berpatokan pada budaya, mengambil bendabenda yang ada di sekitarnya yang sudah dikenal masyarakat, sedangkan Pierce selalu menentukan sebuah tanda berdasarkan logika. Wujud tanda yang diambil dari budaya berupa benda, hewan, dan tumbuh-tumbuhan yang mudah dikenal, ditemukan dan digunakan oleh masyarakat Desa Lise. Manuq (ayam), penanda yang diambil dari binatang. Tékkosorong (bajak tradisional) penanda yang diambil dari alat pertanian untuk mengolah lahan persawahan. Woromporong dan watampatang, penanda yang diambil dari jenis tumbuhan. Walu dan éppang, penanda yang diambil dari benda. Tanra penanda yang diambil dari tanda itu sendiri dengan mengacu pada tiga bintang di langit. Wara-wara penanda yang diambil dari bara api.

Penelitian ini hanyalah bagian kecil dari sekian banyak aspek yang bisa kita teliti dalam naskah, diharapkan adanya penelitian-penelitian baru dalam bidang filologi di masa yang akan datang sebagai usaha nyata mencintai kebudayaan sendiri.

\section{Referensi}

Ambo Enre, Fahruddin. 1983. Ritumpanna Wéleréngnge: Telaah Filologis Sebuah Episode Sastra Bugis Klasik (Disertasi Doktor). Jakarta: Universitas Indonesia.

Arikunto, Suharsimi. 2006. Prosedur Penelitian: Suatu Pendekatan Praktik. Jakarta: Rineka Cipta.

Baried, Siti Baroroh, dkk. 1985. Pengantar Teori Filologi. Jakarta: Pusat Pembinaan dan Pengembangan Bahasa, Departemen Pendidikan dan Kebudayaan

Berger, Arthur Asa. 1998. Media Analysis Techniques, 2nd edition, Thousand. Oakes: Sage

Berger, Arthur Asa. 2000. Signs in Contemporary Culture An Introduction to Semiotics, pent Dwi Marianto (Tanda-tanda dalam Kebudayaan Kontemporer). Yogyakarta: Tiara Wacana Yogya

Berger, Arthur Asa. 2010. Signs in Contemporary Culture: An Introduction to Semiotics, Pengantar Semiotika: Tanda-Tanda dalam Kebudayaan Kontemporer, terj. M.Dwi Marianto. Yogyakarta: Tiara Wacana

Bertens, K. 1985. Filsafat Barat Abad XX (Jilid II): Prancis. Jakarta: Gramedia

Christomy, I. \& Untung Yuwono. 2004. Semiotika Budaya. Pusat Penelitian Kemasyarakatan dan Budaya. Direktorat Riset dan Pengabdian Masyarakat Universitas Indonesia.

Daeng Kulle, Syarifuddin dan Zainuddin Tika. 2008. Aksara Lontarak Makassar. Vol.1 Makassar: Pustaka Refleksi

Djamaris, Edwar. APU. 2002. Metode Penelitian Filologi. Jakarta : CV. Manasco 
Dul Abdul Rahman. 2012. La Galigo - Napak Tilas Manusia Pertama di Kerajaan Bumi. Yogyakarta: Diva Press

Eco, Umberto. 1984. The Name of the Rose. Picador, London: Picador

Eco, Umberto. 1996. Sebuah Pengantar Menuju Logika Kebudayaan, dalam Serba-Serbi Semiotika. terj. Lucia Hilman. Jakarta: Gramedia Pustaka Utama

Hadrawi, Muhlis. 2017. Assikalaibineng. “Kitab Persetubuhan Bugis”. Makassar: Penerbit Ininnawa

Hidayat, Asep Ahmad. 2009. Filsafat Bahasa: Mengungkap Hakikat Bahasa, Makna, dan Tanda. Bandung: Remaja Rosdakarya

Hoed, Benny H. 2001. Dari Logika Tuyul ke Erotisme. Magelang: Yayasan IndonesiaTera Anggota IKAPI

Hoed, Benny H. 2011. Semiotik \& Dinamika Sosial Budaya. Depok: Komunitas Bambu.

Ismail Suardi Wekke. 2013. Islam dan Adat: Tinjauan Akulturasi Budaya dan Agama... Analisis, Volume XIII, Nomor 1, Juni. Sekolah Tinggi Agama Islam Negeri (STAIN) Sorong.

Koentjaraningrat. (1979). Pengantar Ilmu Antropologi. Jakarta: PT. Rineka Cipta

Koolhof, Sirtjo. 1992. Dutana Sawerigading: Een Scene uit de I La Galigo. Skripsi, Universitas Leiden.

Kridalaksana, Harimurti. 1993. Kamus Linguistik. Jakarta: Gramedia

Kriyantono, Rachmat. 2006. Teknik Praktis Riset Komunikasi. Jakarta: Prenada

Kurniawan. 2001. Semiologi Roland Barthes. Magelang: Yayasan Indonesia Tera

Mahsun. 2005. Metode Penelitian Bahasa: Tahapan Strategi, Metode, dan Tekniknya. Jakarta: PT Raja Grafindo Persada

Nöth, Winfried. 1990. Handbook of Semiotics. Indianapolis: Indiana University Press.

Nöth, Winfried. 1995. Semiotik. Handbook of Semiotics (Advance in Semiotics) Terjemahan. Editor: Abd. Syukur Ibrahim. Airlangga University Press.

Nurgiyantoro, Burhan.2000.Teori Pengkajian Fiksi. Yogyakarta:Gajah Mada Press.

Pelras, Christian. (2000). Le Ciel Et Les Jours, Constellations Et Calendries Agraires Chez Les Gugis. Jurnal.

Rahman, Nurhayati. 2006. Cinta, Laut dan Kekuasaan Dalam Epos La Galigo. Makassar: La Galigo Press

Sartini, Ni Wayan. 2009. Menggali Nilai Kearifan Lokal Budaya Jawa Lewat Ungkapan (Bebasan, Saloka dan Paribasa). Logat Jurnal Ilmiah Bahasa Dan Sastra, Volume V No. 1 April

Saussure, Ferdinand de. 1973. Cours de Linguistique Generale. Paris: Payot. Terj. Hidayat, Rahayu S. 1988. Pengantar Linguistik Umum. Yogyakarta: Gajah Mada University Press. 
Sobur, Alex. 2001. Analisis Teks Media Suatu Pengantar untuk Analisis Wacana, Analisis Semiotik, dan Analisis Framing. Bandung: PT. Remaja Rosdakarya.

Sudjiman, Panuti \& Zoest, Aart van. 1992. Serba-Serbi Semiotika. Jakarta: Gramedia Pustaka Utama.

Suyanto, Bagong. 2004. Sosiologi Teks Pengantar dan Terapan. Jakarta: Prenada Media Group

Tim Penyusun. 2007. Kamus Besar Bahasa Indonesia. Jakarta: Balai Pustaka.

Tol, Roger. 2017. La Galigo Menurut naskah NBG 188. Jakarta: Pustaka - Yayasan Obor Indonesia

Van Zoest, Aart. 1993. Semiotika: Tentang Tanda, Cara Kerjanya dan Apa yang kita Lakukan Dengannya. Jakarta: Yayasan Sumber Agung

Yunus, Pangeran Paita. 2013. Bentuk, Gaya, Fungsi, Dan Makna Simbolik Seni Hias Istana-Istana Raja Bugis. Disertasi. Yogyakarta: Universitas Gadjah Mada

Yusmar, Syarifuddin. Penanggalan Bugis-Makassar Dalam Penentuan Awal Bulan Kamariah Menurut Syari'ah Dan Sains. Jurnal Hunafa, Vol.5, No.3, Desember 2008:265-286

Zoest, Aart Van. 1996. Interpretasi dan Semiotika, dalam Serba-Serbi Semiotika, Terj. Okke K.S. Zaimar dan Ida Sundari Husein. Jakarta: Gramedia Pustaka Utama.

\section{Artikel Database}

Badollah, Muhammad Zainuddin. 2015. Review Buku Kebudayaan Bugis oleh Prof.Dr.H.Abu Hamid Sulawesi Selatan. Diakses dari: http://www.kompasiana.com/muhammad-zainuddin badollahi/ review-bukukebudayaan-bugis-oleh-prof-dr-h-abu-hamid-sulawesi-selatan_54f94060 a33311 126 78b4ca4 . [17 Juni 2015] pukul 18:16

Dhitasari, Ni Nyoman Ayu Cinde 2015: Pleiades: dan Mitologi dan signifikansinya dalam Budaya Jawa. http://googleweblight.com/?lite url=http://www.infoastronomy.org/2016/12/mengamati-gugusbintang-pleiades- $\quad$ di-langit-malam.html?m\%3D1\&ei=DWT6UTkS\&lc=idID\&s $=1 \& \mathrm{~m}=563 \&$ host $=$ www.google.co.id\&ts $=149087$ 1970\&sig=AJsQQ1C6dmnxf119iuBtiLs8HhvblE9HvA

Hadi G, Eko. 2011. Mengenal Rasi Gubuk Penceng atau Rasi crux. http://kafeastronomi.com/mengenal-rasigubuk-penceng-atau-rasi-crux.html

KAFI NKCL, 2016. Ada Penampakan Cahaya Berbentuk Batang Di Pusat Galaksi Bima Sakti. http://www.kafinkcl.com/2016/12/ada-penampakan-cahaya-berbentuk-batang.html?m=1

Marpaung, Rosa 2013: Beberapa Rasi Bintang dan Mitologinya. http://googleweblight.com/?lite_url=http:// chochomami. blogspot.com/2013/12/beberapa-rasi-bintang-danmitologinya.html?m\%3D1\&ei=fpsztYtE\&lc=id-ID\&s=1\&m $=563 \&$ host $=$ www.google.co.id\&ts=1490875407\&sig=AJsQQ1CboX14UE6ocsJckSe7bNUKmW2 O_A

Sartini, Ni Wayan. Jurnal: Tinjauan Teoritik tentang Semiotik. Jurusan Sastra Indonesia, Fakultas Sastra, Universitas http://www.journal.unair.ac.id/filerPDF/Tinjauan\%20Teoritik\%20tentang\%20Semiotik.pdf 
(IJES)

ISSN 2622-6197 (Online)

ISSN 2655-4402 (Cetak)

Sumintarsih, Suhartinah, Noor Sulistyo Budi - 1993. Kearifan Tradisional Masyarakat Pedesaan Dalam Hubungannya pemeliharaan lingkungan hidup. DIY. DEPDIKBUD. https://books.google.co.id/books?id=11KhCgAAQBAJ

Wikipedia. Alpha Centauri. https://id.wikipedia.org/wiki/Alpha_Centauri 